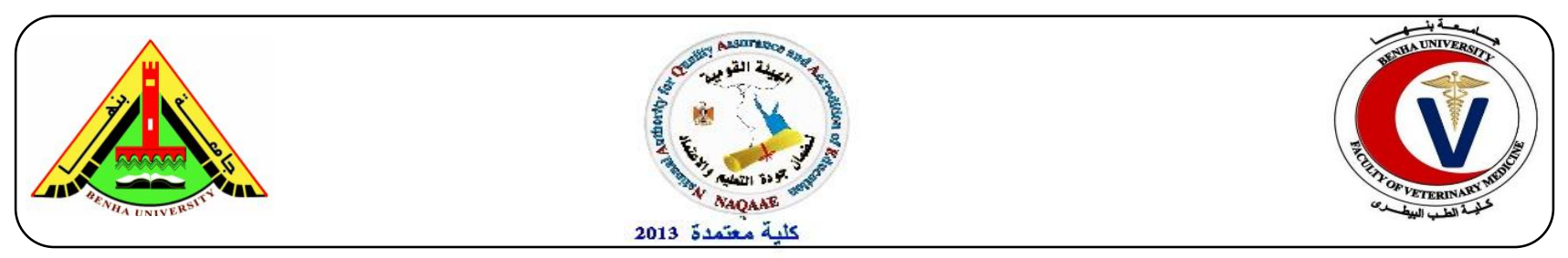

\title{
Natural co-infection of Escherichia coli and Infectious bronchitis virus in broilers and layers flocks
}

\author{
Ashraf A. Abd El-Twab ${ }^{1}$, Saad S. A. Sharawi ${ }^{\mathbf{2}}$, Soad A. Nasef ${ }^{\mathbf{3}}$, Fatma I. El-Hofy ${ }^{\mathbf{1}}$, Ahmed Sedeek ${ }^{\mathbf{3}}$. \\ ${ }^{1}$ Department of Bacteriology, Immunology and Mycology, Faculty of Veterinary Medicine, Benha University \\ ${ }^{2}$ Department of Virology, Faculty of Veterinary Medicine, Benha University \\ ${ }^{3}$ Reference Laboratory For Veterinary Quality Control on Poultry Production, Animal Health Research institute, \\ Dokki, Giza, Egypt
}

\begin{abstract}
A B S T R A C T
The present study was designed to throw the light on isolation of Escherichia coli (E. coli) strains accompanied by Infectious bronchitis virus (IBV). Classification and serotyping of bacterial isolates of E.coli were done followed by their antimicrobial susceptibility testing, also isolation and identification of IBV was done. For that purpose, a total of 200 organs, swap and samples were aseptically collected from broilers and layers flocks suffered from respiratory symptoms and general illness from both private and governmental farms during the period from 2015 till the end of 2017. Results revealed that the prevalence of E. coli was $67.5 \%$ and IBV was $61.5 \%$ in the collected samples. The serological identification showed that the most predominant serotype for E. coli was O 158 and there was a high level of resistance of isolated strains against doxycycline and tetracycline.
\end{abstract}

Keywords: Broiler, E. coli, O158, IBV, co-infection.

(http://www.bvmj.bu.edu.eg)

(BVMJ-34(2): 213-220, 2018)

\section{INTRODUCTION}

Diseases of the respiratory tract are a significant component of the overall disease incidence in poultry. In many cases, respiratory disease observed in a flock may be a component of a multisystemic disease or it may be the predominant disease with lesser involvement of other organ systems. In some cases, such as infectious coryza or infectious laryngotracheitis, the disease may be limited to the respiratory system, at least initially. Various pathogens may initiate respiratory disease in poultry including a variety of viruses, bacteria and fungi. Environmental factors may augment these pathogens to produce the clinically observed signs and lesions (Glisson, 1998).

Infectious bronchitis virus (IBV) is a single stranded positive sense, enveloped RNA virus (Lai and Cavanagh, 1997). The virus has been classified under the Gammacoronavirus genus in the family Coronaviridae, Order Nidovirales. Like other members of coronavirus family, the IBV genome is composed of structural and nonstructural proteins. Infectious bronchitis virus (IBV) is one of the major economically important 
poultry viral diseases distributed worldwide (OIE, 2013).

It affects both galliform and nongalliform birds. Its economic impact includes decreased egg production and poor egg quality in layers, stunted growth, poor carcass weight, and mortality in broiler chickens. (Bande et al., 2016).

E. coli strains causing systemic disease in poultry (avian colibacillosis) are termed avian pathogenic E. coli (APEC). Colibacillosis is a disease of severe economic significance to all poultry producers worldwide and is characterized by a diverse array of lesions (Dziva and Stevens, 2008). These lesions varied between perihepatitis, airsacculitis and pericarditis, or other syndromes such as egg peritonitis, salpingitis, coligranuloma, omphlitis, cellulitis and osteomyelitis/ arthritis (Barnes and Gross, 1997).

Co-infection of $E$. coli with infectious bronchitis virus (IBV) may lead to a more complex outcome, usually associated with high morbidity and mortality. Similarly, infection with nephropathogenic IBV strains may result in pale, swollen, and mottled kidneys (Boroom and et al., 2012).

Therefore, the present study was planned out to throw a light on the natural co-infection of isolated bacterial strains (E. coli) and IBV.

\section{Materials and methods}

\subsection{Sample collection:}

Birds showing symptoms of respiratory diseases and general illness were collected and submitted to the Reference Laboratory for Veterinary Quality Control on Poultry Production, Dokki, for investigating coinfection of respiratory viral infection (IBV) with E.coli infection in broilers and layers flocks. The birds were obtained from both private and governmental farms during the period from 2015 - 2017. A total of 200 broiler and layer flocks (200 samples) examined Organs and swabs were collected aseptically to prevent cross contamination. The collected organs were cultured within a time limit which did not exceed 24 hours from collection.

\subsection{Bacterial isolation and identification:}

Preparation of samples:

The internal organs included liver, spleen, heart and other organs were prepared for isolation of E.coli according to (Quinn et al., 2002).

Microscopic examination:

Gram's stain was prepared and used as described by Cruickshank et al., (1975) for morphological study.

Biochemical Identification:

According to Quinn et al., (2002) including Indole reaction, Methyl red test, Voges Proskauer test, Citrate utilization test, Catales test, Sugar fermentation test, Oxidase test, Triple sugar iron and Christener's urea agar test.

Serological identification of E. coli isolates: Typing of E. coli isolates was performed by the slide agglutination test using standard polyvalent and monovalent E. coli antisera according to Edwards and Ewing., (1972).

\subsection{Determination of antimicrobial} susceptibility profiles for E. coli isolates (CLSI, 2007):

The disk diffusion technique was applied according to (CLSI, 2007). The following antibiotics were used (Doxycycline, Sulphamethoxazole/trimethoprim,

Levofloxacin, Norfloxacin, Nitrofurantin, Ampicillin, Ciprofloxacin, Gentamycin, Tetracycline and Chloramphenicol) and interpreted according to (CLSI, 2007).

\subsection{Viral identification:}

Preparation of samples for IBV detection: 
The collected organs (Trachea, lung and kidney) were washed in sterile saline, and then frozen at below $-10^{\circ} \mathrm{C}$. After thawing, the tissue homogenates $(10 \% \quad w / v)$ were suspended in sterile saline $(0.85 \% \mathrm{w} / \mathrm{v})$ containing $100 \mathrm{IU} / \mathrm{mL}$ penicillin, $1.0 \mathrm{mg} / \mathrm{ml}$ streptomycin. By disrupting organs using sterile mortar and pestle, the homogenates were then centrifuged at $3000 \mathrm{rpm}$ for $10 \mathrm{~min}$, and the supernatant was further passed through $0.22 \mu \mathrm{m}$ membrane filter for clarification. The supernatant was subjected to RNA extraction (OIE, 2013).

Detection of IBV directly from samples using RRT-PCR:

\section{RNA extraction}

RNA was extracted from the prepared suspension QIAamp Viral RNA Mini Kit(Qiagen, Valencia, Calif., USA,Cat. No. 52904.). The procedure was performed according to the company's instruction.

The extracted viral RNA was preserved at $70^{\circ} \mathrm{C}$ until subjected for RRT-PCR.

Amplification of the extracted RNA by Real Time-RT-PCR (RRT-PCR)

Amplification was done using Quantitect RTPCR(Qiagen, Inc. Valencia CA) in accordance with kit instruction In brief one reaction formed from $12.5 \mu$ l RT-PCR Master Mix, $6.6 \mu 1$ Rnase free water, $0.5 \mu 1$ for each primer and $0.125 \mu l$ probe. Oligonucleotide primers and probe used in real time PCR as previously described by Meir et al. (2010) in concentration of 50 pmol for primers and 30 pmol for probe, Briefly, foreword primer so named AIBV-fr 5, ATGCTCAACCTTGTCCCTAGCA 3' and reverse primer so named AIBV-as 5, TCAAACTGCGGATCATCACGT'3 and probe so named AIBV-TM (5'FAMTTGGAAGTAGAGTGACGCCCAAACTTC A-TAMRA'3. Amplification conditions were Reverse transcription for $30 \mathrm{mins}$ at $50{ }^{\circ} \mathrm{C}$, primary denaturation for $15 \mathrm{~min}$ at $95{ }^{\circ} \mathrm{C}$ and then cycling steps $95{ }^{\circ} \mathrm{C}$ for $15 \mathrm{sec}$ for $2^{\text {nd }}$ denaturation and then $60{ }^{\circ} \mathrm{C}$ for $45 \mathrm{sec}$ for annealing and extension. that repeated for 40 cycles.

\section{RESULTS}

Bacterial isolation and serological identification.

The prevalence of E.coli infection reached $67.5 \%$ (135 out of 200 samples) many chickens showing symptoms of colisepticemia. The incidence of $E$. coli infection was 120 samples out of 160 samples with a percentage $75 \%$ in broiler and 15 out of 40 samples with a percentage $37.5 \%$ in layers Table (1).

Prevalence of E. coli strains in isolates from broilers and layer flocks.

Serotyping of 135 E.coli isolates was applied by slide agglutination test using polyvalent and monovalent $\mathrm{O}$ E.coli antisera. 14 different serotypes were identified among E.coli isolates and the most predominant serotypes were O158:k- ,O25:k11, O26:k60 ,O78:k80 and $\mathrm{O} 44: \mathrm{k} 74$ on the other hand $11.1 \%$ of isolates were untypable this showed in table (2)

\section{Antimicrobial susceptibility test.}

A high level of resistance of E.coli isolates was recorded to doxycycline $(67.5 \%)$ and tetracycline $(65 \%)$ followed by Nitrofurantin (64.2\%), ampicillin (58.3\%) finally Ciprofloxacin $(6.7 \%)$ as shown in table (3).

Result of viral isolation.

Prevalence of $I B V$ recovered from different flocks:

The result of virus detection by real time RTPCR revealed that 103 out of 160 examined samples were positive for IBV with a percentage of $64.3 \%$ in broilers, while in layers 20 samples out of 40 were positive for IBV with a percentage of $50 \%$. Meanwhile the total percentage of detection was $61.5 \%$ 
Table (4). Also studying occurrence of IBV and E. coli combined infection revealed that E. coli+ IBV was $20 \%$ as shown in table (5) where E. coli alone prevalence percentage was $47.5 \%$ and IBV alone was $41.5 \%$.

Table 1: Prevalence of E. coli recovered from broilers and layers flocks.

\begin{tabular}{llll}
\hline Type of flocks & $\begin{array}{l}\text { Number of } \\
\text { examined samples }\end{array}$ & $\begin{array}{l}\text { Number of +ve } \\
\text { samples }\end{array}$ & $\%$ of +ve samples \\
\hline Broilers & 160 & 120 & 75 \\
Layers & 40 & 15 & 37.5 \\
Total & 200 & 135 & 67.5 \\
\hline
\end{tabular}

Table 2: Prevalence of E. coli strains in isolates from broilers and layer flocks.

\begin{tabular}{lll}
\hline Serotype & Serotype number & Percentage of serotype \\
\hline O158:k- & 18 & 13.3 \\
O25:k11 & 15 & 11.1 \\
O26:k60 & 11 & 8.1 \\
O78:k80 & 10 & 7.4 \\
O44:k74 & 9 & 6.7 \\
O114:K90 & 9 & 6.7 \\
O119:k69 & 8 & 6 \\
O103:K- & 8 & 6 \\
O127:K63 & 7 & 5.2 \\
O125:K70 & 7 & 5.2 \\
O86:K- & 6 & 4.4 \\
O91:K- & 5 & 3.7 \\
O111:K58 & 4 & 3 \\
O8:K50 & 3 & 2.2 \\
Untypaple & 15 & 11.1 \\
\hline
\end{tabular}

Table 3: Antibiogram profile of each antimicrobial against E. coli isolates from chicken.

\begin{tabular}{|c|c|c|c|c|c|c|c|c|c|c|}
\hline Isolate & DO & TE & $\mathrm{F}$ & AMP & $\mathrm{C}$ & $\mathrm{CN}$ & LEV & SXT & NOR & CIP \\
\hline \multicolumn{11}{|l|}{ Sensitive } \\
\hline NO. & 10 & 13 & 14 & 19 & 34 & 28 & 50 & 43 & 65 & 103 \\
\hline$\%$ & $8.3 \%$ & $10.8 \%$ & $11.6 \%$ & $15.8 \%$ & $28.3 \%$ & $23.3 \%$ & $41.7 \%$ & $35.8 \%$ & $54.2 \%$ & $85.8 \%$ \\
\hline \multicolumn{11}{|l|}{ Intermediate } \\
\hline NO & 29 & 29 & 29 & 31 & 36 & 45 & 25 & 35 & 25 & 8 \\
\hline$\%$ & $24.2 \%$ & $24.2 \%$ & $24.2 \%$ & $25.8 \%$ & $30 \%$ & $37.5 \%$ & $20.8 \%$ & $29.2 \%$ & $20.8 \%$ & $6.7 \%$ \\
\hline \multicolumn{11}{|l|}{ Resistant } \\
\hline NO. & 81 & 78 & 77 & 70 & 50 & 47 & 45 & 42 & 30 & 9 \\
\hline$\%$ & $67.5 \%$ & $65 \%$ & $64.2 \%$ & $58.4 \%$ & $41.7 \%$ & $39.2 \%$ & $37.5 \%$ & $35 \%$ & $25 \%$ & $7.5 \%$ \\
\hline
\end{tabular}

Doxycycline. (DO), Sulphamethoxazole/trimethoprim. (SXT), Levofloxacin.(LEV), Norfloxacin.(NOR), Nitrofurantin.(F), Ampicillin. (AMP), Ciprofloxacin. (CIP), Gentamycin.(CN), Tetracycline.(TE), Chloramphenicol.(C) 
Table 4: Prevalence of IB virus recovered from different flocks.

\begin{tabular}{llll}
\hline Type of flocks & $\begin{array}{l}\text { Number } \\
\text { examined samples }\end{array}$ & $\begin{array}{l}\text { of } \\
\text { Samples }\end{array}$ & $\begin{array}{l}\text { of } \\
\text { Sam of +ve samples }\end{array}$ \\
\hline Broilers & 160 & 103 & 64.3 \\
Layers & 40 & 20 & 50 \\
Total & 200 & 123 & 61.5 \\
\hline
\end{tabular}

Table 5: Prevalence of co-infection.

\begin{tabular}{lll}
\hline Type of infection & Number of +ve samples & $\%$ of +ve samples \\
\hline E. coli alone & 95 & 47.5 \\
IBV alone & 83 & 41.5 \\
E. coli + IBV & 40 & 20 \\
\hline
\end{tabular}

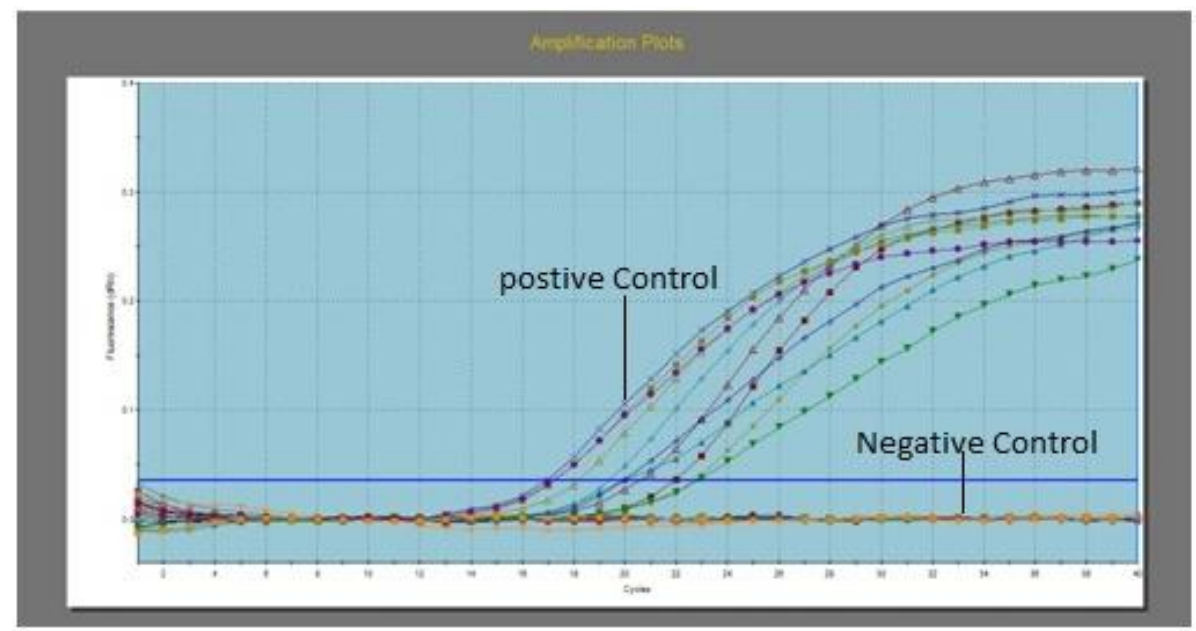

Fig.1. Amplification curves of the tested positive samples

\section{DISCUSSION}

In the present work it was recorded that the prevalence of isolation of E.coli reached $67.5 \%$ from the examined 200 samples showing symptoms of colisepticaemia. Almost similar percentages 67\% in chickens were reported by Syuhada et al., (2013), and Stella et al., (2016) reported that From the 80 sampled birds, $48(60 \%)$ E. coli was detected of them. While a higher incidence of $85.2 \%$ was reported by Wani et al., (2004), and Albarri et al., (2017) where it was $(93.75 \%)$.
On the other side a lower incidence (20.5\%) was recorded by Saidi et al., (2013) and (43.1\%) by Roshdy et al., (2012).

The result of serotyping revealed that, the most commonly isolated serotypes were O158, O26, O78,O44, O114,0119,0103 ,O127, O125 ,O86, O91and O111. These result mostly similar to another study was conducted by Roshdy et al., (2012). Also Abd El-Twab et al., (2015) reported that the most commonly serogroups isolated from chickens were $\mathrm{O} 44, \mathrm{O} 158, \mathrm{O} 125$ and $\mathrm{O} 103$.

In the present study the susceptibility of E.coli isolated from broilers and layers 
chicken showed a high sensitivity to Ciprofloxacin. This finding is similar to previous studies conducted by Guerra et al., (2003) and Hasan et al., (2011) which found that $E$. coli isolates were highly sensitive to ciprofloxacin. The high sensitivity to ciprofloxacin might be because it is a broad spectrum antibiotic that is still relatively new and has limited use by poultry farmers. Unlike Omer et al., (2010), who found that avian E. coli isolates were highly resistant to ciprofloxacin. The data of this study showed that there was a high level of resistance against doxycycline, tetracycline and ampicillin. This is go a hand with a several reports (Sharada et al., 2009) and (Zakeri and Kashefi, 2012). The presence of high resistance is probably due to the increased use of antibiotics as feed additives, for example, tetracyclines, bacitracin, and cloxacillin are widely used in poultry industries for growth promotion or prevention of diseases (Omer et al., 2010).

Concerning to viral isolation, a total of 123 samples out of 200 were positive for IBV detection (61.5\% of the samples), where $64.3 \%$ and $50 \%$ of the samples were positive for broilers and layers respectively. Almost similar results were recorded by Roussan et al., (2008) and Zanaty. (2014). While a higher percentage reached to $88 \%$ recorded by Abdel-ElGhany et al., (2015). On the other hand a lower percentage was recorded by Mohamed and Ibrahim (2015) which was $14.28 \%$. It was found that the percentage of co-infection occurrence was $20 \%$ which studied previously by Boroom and et al., (2012), who found that E. coli lead to more exacerbating effect to IBV, which may be due to $E$. coli provide the enzymes capable of cleaving the hemagglutinin of viruses like IBV enabling them to replicate and spread to a greater extent in that host (Bano et al., 2003)
It was concluded that co-infection between Infectious bronchitis virus and E.coli lead to a more complex outcome, than infection with IBV alone so we should give more attention to secondary bacterial infection specially E.coli and take the suitable preventive measures and precautions against them.

\section{REFERENCES}

Abd El-Twab, A. A., Ammar, A. M., Nasef, S. A. and Reda, R. M. (2015): Prevalence of E.Coli in diseased chickens with its antibiogram pattern. Benha Veterinary Medical Journal, Vol. 28, No. 2:224 - 230.

Abdel-ELGhany, S. A., Hussein, H. A., Arafa, A., Zanaty, A. and Shalaby, M. A. (2015): Molecular Characterization of Is/1494-Like Strains of Infectious Bronchitis Virus (IBV) in Commercial Breeders and Layer Chicken in Egypt during Years 2012 to 2014. Global Veterinaria 15 (3): 278-283.

Albarri, O., Var, I., Meral, M., bedir, B., Heshmati, B. and Fatih Köksal. (2017): Prevalence of Escherichia coli isolated from meat, chicken and vegetable samples in Turkey Journal of Biotechnology Science Research. 4(3):214-2022.

Bande, F., Arshad, S. S., Omar, A., Bejo, M. H., Abubakar, M. S. and Abba, Y. (2016): Pathogenesis and Diagnostic Approaches of Avian Infectious Bronchitis. Advances in Virology. Article ID 4621659,11 pages.

Bano, S., Naeem, K., and Malik, S. A. (2003): Evaluation of Pathogenic Potential of Avian Influenza Virus Serotype H9N2 in Chickens. Avian Diseases 47:817822 . 
Barnes, H. J. and Gross, W.B. (1997): Colibacillosis. In B.W. Calnek, H.J. Barnes, C.W. Beard, L.R. McDougald \& Y.M. Saif (Eds.), Diseases of Poultry, 10th edn (pp. 131141). Ames, IA: Iowa State University Press.

Boroomand, Z., Asasi, K. and Mohammadi, A. (2012): Pathogenesis and tissue distribution of avian infectious bronchitis virus isolate IRF-IBV32 (793/B serotype) in experimentally infected broiler chickens," The Scientific World Journal, vol. 2012,Art ID 402537, 6 pages.

Clinical and laboratory standard institute(CLSI). (2007): antimicrobial susceptibility standard vol.27 no.1.

Cruickshank R., Duguid J.P., Marmion B.P. and Swain R.H.A. (1975): Medical Microbiology, 12th ed., Vol. II Churchill living stone, Edenburg, London and New York. Page 43, 51.

Dziva, F. and Stevens, M. P. (2008): Colibacillosis in poultry. Unraveling the molecular basis of virulence of avian Pathogenic E. coli in their natural hosts. Avian Pathol. 37(4):355-366.

Edwards, P. R. and Ewing, W.H. (1972): Identification of Enterobacteriacae. Minneapolis, Burgess Publishing Co., PP. 709.

Glisson, J. R. (1998): Bacterial Respiratory Diseases of Poultry. Poultry Science 77:1139-1142.

Guerra, B., Junker, Schroeter, A., Malorny, B., Lehmann, S. and Helmuth, R. (2003): Phenotypic and genotypic characterisation of antimicrobial resistance in German Escherichia coli isolates from cattle, swine and poultry. J. Antimicrob. Chemother. 52:489-
492.

Hasan, B., Faruque, R., Drobni, M., Waldenstro“m, J., Sadique, A., Ahmed, K. U. and Alam, M. (2011): High prevalence of antibiotic resistance inpathogenic Escherichia coli from large- and small-scale poultry farms in Bangladesh. Avian Dis. 55(4):689692.

Lai, M. M. and Cavanagh, D. (1997): The molecular biology of Coronaviruses, Advances in Virus Research, vol. 48, pp. 1-100.

Meir, R., Maharat, O., Farnushi, Y. and Simanov, L. (2010): Development of a real-time TaqMan ${ }^{\circledR}$ RT-PCR assay for the detection of infectious bronchitis virus in chickens, and comparison of RT-PCR and virus isolation. Journal of Virological Methods, 163: 190-194.

Mohamed M. A. and Ibrahim A. A. (2015): Evolution of New Variant Strains of Infectious Bronchitis Virus Isolated from Broiler Chickens. International Journal of Animal and Veterinary Sciences (IJAVS) Volume 1, Issue 1, PP 1-11.

OIE, (2013): Avian Infectious Bronchitis. OIE Terrestrial Manual 2013. Pp: 443455. Office International des Epizooties, Paris. Chapter 2.3.2.

Omer, M. M., Abusalab, S. M., Gumaa, M. M., Mulla, S. A., Omer, E. A., Jeddah, I. E. and Ahmed, A. M. (2010): Outbreak of colibacillosis among broiler and layer flocks in intensive and semi intensive poultry farms in Kassala State, Eastern Sudan. Asian J. Poultry Sci. 4(4):173-181.

Quinn, P. J., Markey, B. K., Carter, M. E., Donnelly, W. J. C. and Leonard, F. C. 
(2002): Veterinary microbiology and microbial diseases. $1^{\text {st }}$ Iowa State University Press Blackwell Science.

Roshdy, H., Nasef, S. A. and Refai, M. (2012): Incidence of E. coli in chickens and ducks in different governorates in Egypt.1st Conf. of An. Health Res. Inst. Assoc., pp. 420 - 426.

Roussan, D. A., Totanji, W. S. and Khawaldeh, G. Y. (2008): Molecular Subtype of Infectious Bronchitis Virus in Broiler Flocks in Jordan. Poultry Science 87:661-664 .

Saidi, B., Mafirakureva, P. and Mbanga, J. (2013): Antimicrobial Resistance of Escherichia coli Isolated from Chickens with Colibacillosis in and Around Harare, Zimbabwe. Avian Diseases 57:152-154.

Sharada, R., Ruban, S. W. and Thiyageeswaran, M. (2009): Antibiotic resistance pattern of Escherichia coli isolated from poultry in Bangalore. Internet J. Microbiol. 7(1).doi: 10.5580/2164.

Stella, A. E., De Oliveira, M. C., Fontana, V. L. D. S., Maluta, R. P., Borges C. A. and Ávila, F. A. (2016): Characterization and antimicrobial resistance patterns of Escherichia coli isolated from feces of healthy broiler chickens. Arq. Inst. Biol., v.83, 1-5, e0392014.

Syuhada, N. Z. A., Hair-Bejo, M., Zunita, Z., Omar, A. R. and Khairani-Bejo, S. (2013): isolation of Escherichia coli from various organs of broiler Chickens with complicated chronic respiratory disease. Wpsa \& wvpa conference, at faculty of veterinary medicine, universiti putra malaysia,
Selangor.

Wani, S. A., Samanta, I., Bhat, M. A. and Nishikawa, Y. (2004): Investigation of shiga toxin-producing Escherichia coli in avian species in India. Applied Microbiology. 39, 389-394.

Zakeri, A., and Kashefi, P. (2012): Antimicrobial susceptibilities of avian Escherichia coli isolates in Tabriz, Iran. Afr. J. Biotechnol. 11(19):44674470 .

Zanaty, A. M. M. (2014): Epidemiological and molecular studies on the current status of infectious bronchitis disease in Egypt[PhD thesis] Egypt: Faculty of Veterinary Medicine, Beni-Suef University. 